\title{
カルシウムユニポーターによるミトコンドリアカルシウム取り込みの分子機構
}

\author{
山本武範 $a, b, \uparrow$
}

\section{The Molecular Mechanisms of Mitochondrial Calcium Uptake by Calcium Uniporter}

\author{
Takenori Yamamoto ${ }^{a, b, \uparrow}$ \\ anstitute for Genome Research, Tokushima University; 3-18-15 Kuramoto-cho, Tokushima 770-8503, Japan: and \\ ${ }^{b}$ Faculty of Pharmaceutical Sciences, Tokushima University; 78-1 Shomachi-1, Tokushima 770-8505, Japan.
}

(Received August 31, 2020)

\begin{abstract}
Mitochondria play a role as intracellular calcium stores as well as energy conversion functions. Excessive calcium accumulation in mitochondria induces cell death and induces diseases such as ischemia-reperfusion injury. Mitochondrial calcium uptake is considered to be mediated by calcium uniporters, which have attracted much attention as potential drug targets. Although calcium uniporter was shown to function as an ion channel, the molecular mechanisms have long been unclear. In this decade, the molecular composition of the calcium uniporter complex was discovered; the calcium uniporter consists of the 7 subunits. Each subunit has no structural similarity to other $\mathrm{Ca}$ ion channels; thus, the novel molecular mechanism of the $\mathrm{Ca}^{2+}$ uptake by calcium uniporter is of interest. Although calcium uniporter is conserved in human to warm, yeast lack mitochondrial calcium uptake activity. In the previous study, various subunits of mammalian calcium uniporter were expressed in the yeast mitochondria. As a result, although the expression of each subunit alone did not affect on the mitochondrial calcium uptake activity, the co-expression of mitochondrial calcium uniporter (MCU) and essential MCU regulator (EMRE) enabled to reconstitute calcium uptake activity in yeast mitochondria. This indicated that MCU and EMRE are key factors of the calcium uptake activity in mitochondria. This yeast reconstitution technique has also enabled us to perform detailed structure-function analysis of the MCU and EMRE. In this paper, we will discuss the molecular mechanism of $\mathrm{Ca}^{2+}$ uptake and the prospects for drug discovery.
\end{abstract}

Key words_-mitochondria; calcium; ion channel; yeast

\section{1. はじめに}

$\mathrm{Ca}^{2+}$ は生体内の様々な場面で重要な役割を果た すシグナリングイオンである。その働きは筋収縮や 受精に始まり細胞死に至るまで多岐にわたり，“生 と死をつかさどるイオン”ということができる，こ のため, $\mathrm{Ca}^{2+}$ の細胞内濃度は厳密に制御されてい る. 真核細胞において最も重要な $\mathrm{Ca}^{2+}$ レギュレー ターの 1 つはミトコンドリアであり，ミトコンドリ アでの $\mathrm{Ca}^{2+}$ 動態の異常が虚血再灌流障害, ウル リッヒ型筋ジストロフィー, アルツハイマー病，ハ ンチントン病などの病態を引き起こすことが明らか

$a$ 徳島大学先端酵素学研究所 ( $7770-8503$ 徳島市蔵本 町 3-18-15), b徳島大学大学院薬科学教育部 ( T7708505 徳島市庄町 1 丁目 78-1)

現所属: ‘国立医薬品食品衛生研究所遺伝子医薬部 （干210-9501 川崎市川崎区殿町 3-25-26）

e-mail: tyamamoto@ nihs.go.jp

本総説は, 日本薬学会第 140 年会シンポジウム S09 で 発表した内容を中心に記述したものである.
にされている.このため, その創薬標的としても注 目が集まっている.しかしながら，ミトコンドリア における $\mathrm{Ca}^{2+}$ 濃度調節に係わる分子メカニズムは 最近までほとんどわかっていなかった．ミトコンド リアによる細胞内 $\mathrm{Ca}^{2+}$ 濃度の調節機構の中核とな るのはミトコンドリアへの $\mathrm{Ca}^{2+}$ 取り込みを行うカ ルシウムユニポーターによる単輸送機構である。 50 年以上にわたり不明であったカルシウムユニポー ターを構成する分子群がここ数年の間に続々と同定 された。これにより，カルシウムユニポーターはポ ア形成サブユニットとそれに結合する複数の調節サ ブユニットによって構成されることがわかってき た. 関連分子の同定により，この複合体がどのよう に $\mathrm{Ca}^{2+}$ を取り込んでいるのか，さらにはなぜその 取り込み機構が細胞や多くの器官の機能に重要なの か，といつたより深い疑問に対してアプローチが可 能になつた。本稿では，われわれがこれまでに明ら かにした知見やここ 1-2 年の立体構造をめぐる混乱 


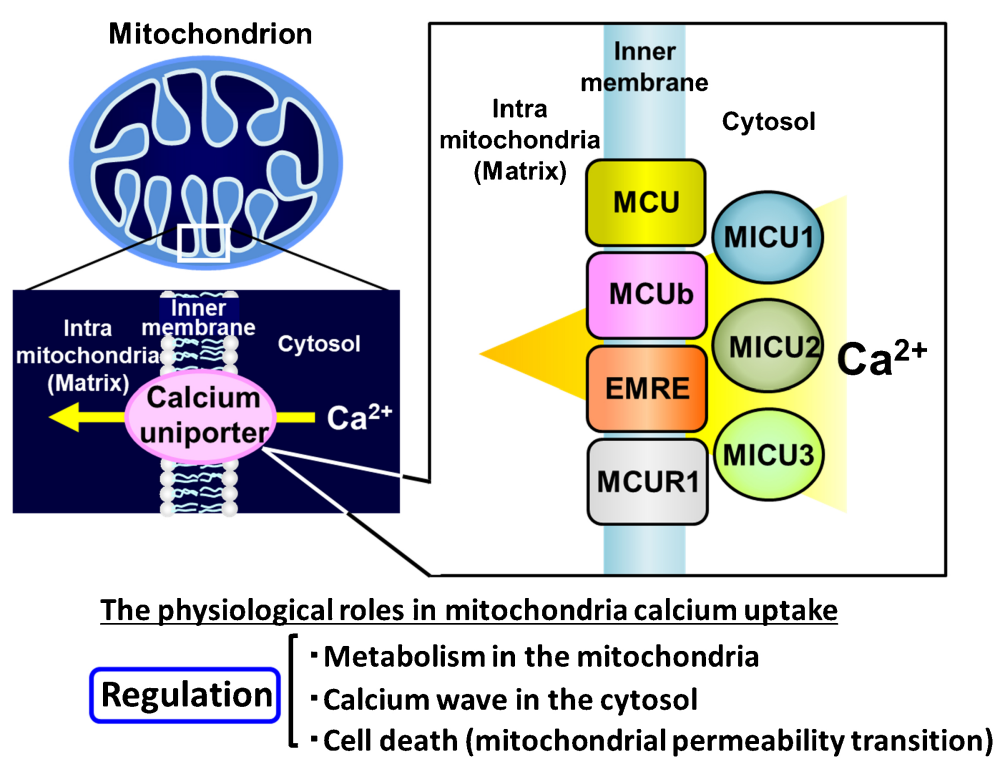

Fig. 1. The Subunits of the Mitochondrial Calcium Uniporter Complex, and the Physiological Roles in Mitochondrial Calcium Uptake

(Color figure can be accessed in the online version.)

を踏まえながら，カルシウムユニポーターが $\mathrm{Ca}^{2+}$ を取り込む分子機構を中心に最新の動向を紹介する とともに，カルシウムユニポーターを標的とする創 薬への展望を議論する.

2. ミトコンドリアカルシウムユニポーター

ミトコンドリアの $\mathrm{Ca}^{2+}$ 取り込みに関する研究は, 1960 年代に複数の研究グループが動物組織から高 純度に精製したミトコンドリアが $\mathrm{Ca}^{2+}$ を取り込み 内部に保持する性質を持つことを報告したことに端 を発する. ${ }^{1)} こ の ~ \mathrm{Ca}^{2+}$ の取り込みは一部の真菌を 除く広い生物種のミトコンドリアで観察され，進化 の過程を通じたその重要性が認識されてきた，その 後，この取り込みはミトコンドリア内膜を介した膜 電位を駆動力として起こること，他の陰イオンや陽 イオンとの交換を必要としないことが示され，この 輸送を担保する分子は “カルシウムユニポーター” と呼ばれるようになった (Fig. 1). $\left.{ }^{2}\right)$ カルシウムユ ニポーターはミトコンドリア外の $\mathrm{Ca}^{2+}$ 濃度が低い ときには $\mathrm{Ca}^{2+}$ 取り込み活性を示さず，ミトコンド リア外 $\mathrm{Ca}^{2+}$ 濃度が高い $(>10 \mu \mathrm{M})$ と取り込夕活 性を示す，というユニークな性質を持ち，このシグ モイド型の $\mathrm{Ca}^{2+}$ 応答性から複数のサブユニットタ ンパク質によって構成されると当初から考えられて いた。 2004 年, Kirichokらのミトコンドリア膜に 対する電気生理学的解析から, 高い $\mathrm{Ca}^{2+}$ 選択性を 持つコンダクタンスが確認されたことにより, ${ }^{3)} こ$
のカルシウムユニポーターがチャネル性の輸送様式 を持つことが明らかにされた。しかしながら，この $\mathrm{Ca}^{2+}$ 取り込みに係わる分子は依然不明のままで あった。

カルシウムユニポーターの生理的役割に関しては 古くから多くの報告がなされている。1980 年代に は，カルシウムユニポーターを介してミトコンドリ アのマトリックス内に取り込まれた $\mathrm{Ca}^{2+}$ がマト リックス内に存在する 3 種類のデヒドロゲナーゼを 活性化して代謝調節に係わることが報告された. ${ }^{4)}$ その後, カルシウムユニポーターは細胞質のカルシ ウムウェーブ $\left(\mathrm{Ca}^{2+}\right.$ 濃度上昇の伝播）に影響を与

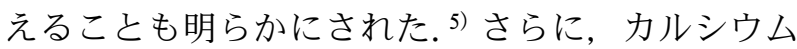
ユニポーターを介してミトコンドリア内に過剩な $\mathrm{Ca}^{2+}$ が取り込まれた場合には，ミトコンドリア内 膜の物質透過性が上昇する現象（透過性遷移）が誘 起され，これが細胞死の引き金を引くこともわかつ た. ${ }^{6}$ 透過性遷移は虚血再灌流障害，ウルリッヒ型

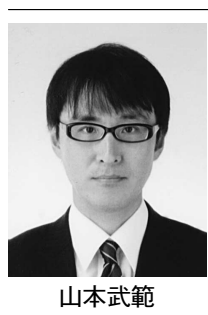

2007 年徳島大学大学院薬科学教育部博 士後期課程を修了, 同大学の（現）先 端酵素学研究所の助教, 2013 年より講 師を経て，2019 年より国立医薬品食品 衛生研究所 - 主任研究官 (徳島大学 先端酵素学研究所・客員教授)。ミトコ ンドリアのカルシウム取り込みの制御 機構とその疾患との係わりなどについ て研究している. 
筋ジストロフィー, アルツハイマー病, ハンチント ン病を始めとする疾患の原因とされ，カルシウムユ ニポーターはこれらの疾患の治療標的として注目さ れている。

\section{3. カルシウムユニポーターによる $\mathbf{C a}^{2+}$ 取り込} みの分子機構

カルシウムユニポーターの生理的な役割に関する 研究が進展する一方で, カルシウムユニポーター自 体が $\mathrm{Ca}^{2+}$ を取り込む分子機構の理解は 50 年以上 の間停滞していた．状況が進展する契機となつたの は，ミトコンドリアを構成するタンパク質のデータ ベース MitoCarta（2008 年）の公開であった.

MitoCarta を基に, 2010 年 Harvard 大学の Mootha らのグループは，ミトコンドリアの $\mathrm{Ca}^{2+}$ 取り込み 能を持たない酵母と $\mathrm{Ca}^{2+}$ 取り込み能を持つトリパ ハソーマの間でミトコンドリアを構成するタンパク 質群を比較することにより, mitochondrial calcium

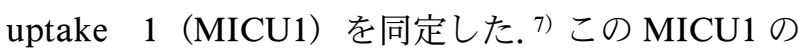
同定を皮切りに, mitochondrial calcium uniporter (MCU ), ${ }^{8,9)}$ またそれらのパラログである, MICU2, ${ }^{10)}$ MICU3 , ${ }^{10)} \mathrm{MCUb},{ }^{11)}$ さらに, 2012 年 には mitochondrial calcium uniporter regulator 1 (MCUR1)，12） 2013 年には essential MCU regulatory element (EMRE) といつた関連分子が次々と同定 された.13)これらの中で脳選択的に存在する MICU3 以外のすべてのサブユニットは全身に分布 している. 現在，カルシウムユニポーターは 6-7 種 のサブユニットで構成された複合体チャネルとして 機能していると考えられている（Fig. 1)。これま でに，MCUがオリゴマー化してチャネル孔を形成 し，他のサブユニットがそのチャネル孔の開閉を調 節していると考えられているが，個々のサブユニッ トの機能に関してはいまだ不明な点が多く残されて いる.これらの分子群には生体内に存在する既知の カルシウムイオンチャネルとの構造的な類似性が認 められないことから，カルシウムユニポーターは新 しいカテゴリーのカルシウムイオンチャネルであ り，その構造機能相関に興味が持たれる。 また，欧 州では MICU1 に点変異を持つ家系において遺伝性 心筋症が認められることが報告され，ミトコンドリ アカルシウム取り込みと疾患との係わりが分子レベ ルで明らかにされ始めている. ${ }^{14)}$

\section{4. $\mathbf{C a}^{2+}$ 取り込みに必須なサブユニットの最小 単位の決定}

これまでにミトコンドリア $\mathrm{Ca}^{2+}$ 取り込みに係わ る 7 つのサブユニットが同定されたものの, $\mathrm{Ca}^{2+}$ 取り込みに必須なサブユニットはどれか? という 疑問は残されたままだつた。そこでまず，研究の焦 点を絞るために，われわれはこの疑問に解答を得る ことを試みた。

これまで, カルシウムユニポーターの分子機構の 研究は特定のサブユニットを欠損させた動物細胞を 使って進められてきた。しかし，このアプローチを

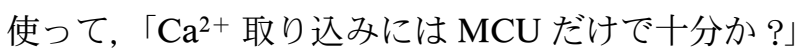
という疑問に答えるには複数の遺伝子の欠損が必要 となる上，傊させた遺伝子の機能が他のサブユ ニットによって代替される可能性も否定できない. このような弱点を回避するため，われわれは酵母に 着目した。 ミトコンドリアへの $\mathrm{Ca}^{2+}$ 取り込み機能 はヒトから真菌まで広く保存されているが, 興味深 いことに酵母 Saccharomyces cerevisiae（以下，酵 母）では欠損している. 実際, 酵母のゲノム上には カルシウムユニポーターのサブユニット群のオルソ ログは認められない。この特性を利用し，酵母に哺 乳類のカルシウムユニポーターのサブユニットを発 現させることにより, カルシウムユニポーターの特 定のサブユニットだけを持つミトコンドリアの調製 が可能である.この方法は内在するサブユニットに 由来する二次的な影響を受けず，個々のサブユニッ トの機能を選択的にミトコンドリア上で解析できる という点で有用である.

このような考えの下，われわれは酵母にマウスの カルシウムユニポーターのサブユニットを発現さ せ，ミトコンドリアに $\mathrm{Ca}^{2+}$ 取り込み活性が認めら れるかを調べた。 その結果, MCU を始めとする各 サブユニットはいずれも単独で発現させても $\mathrm{Ca}^{2+}$ 取り込み活性を示さず，当時はコンセプトが間違つ ているのかと不安になつたが，その後発見されたサ ブユニットについてすべての組み合わせで共発現実 験を行ったところ, MCU と EMRE を共発現させ た場合にのみ顕著な $\mathrm{Ca}^{2+}$ 取り込み活性を示すこと が明らかになった (Fig. 2)。このことは, 既知の $7 \supset$ のサブユニットの中で, MCU と EMRE の 2 つが $\mathrm{Ca}^{2+}$ 取り込みを行う最小単位であることを示して いる. ${ }^{15)}$ また，これによりこの 2 つのサブユニット 
Relative $\mathrm{Ca}^{2+}$ uptake

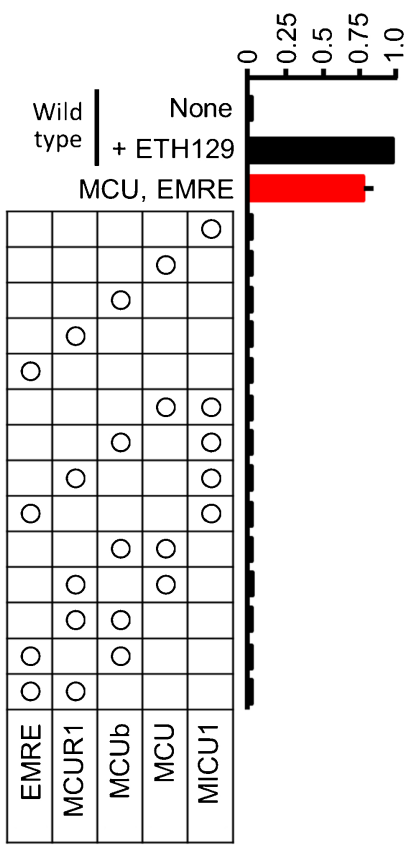

Fig. 2. Relative Calcium Uptake of the Yeast Mitochondria with Mammalian Calcium Uniporter Subunit (s)

The activities of calcium uptake in the mitochondria isolated from yeast with mammalian calcium uniporter subunit (s) were compared. As a positive control, the activities of calcium uptake in the mitochondria isolated from wild-type yeast treated by a calcium ionophore, ETH129, was examined. (Color figure can be accessed in the online version.)

に対する詳細な構造機能解析への道が拓かれた.

5. ミトコンドリア $\mathrm{Ca}^{2+}$ 取り込みにおける EMRE の役割

これまでの知見から，MCU はチャネル孔を形成 することが示唆されている。しかしながら， EMRE はノックアウトした場合に $\mathrm{Ca}^{2+}$ 取り込み機 能が消失することがわかっていたの夕で具体的な役 割は不明であった。そこでわれわれは，まず EMRE に焦点をあて，酵母発現系を使ってその構 造と機能を調べた。 ${ }^{15)}$

\section{5-1. EMRE の構造機能解析 まず， EMRE} がミトコンドリアでの MCU のタンパク質安定性に 寄与する可能性について検討した。その結果， MCU を単独で発現させた場合と EMRE と共発現 させた場合とで，ミトコンドリアでの MCU の存在 量は変化しなかった。 したがって， EMRE は MCU のタンパク質安定性に寄与する因子ではないと考え られた。

一般に，イオンチャネルに存在するいくつかの酸 性アミノ酸が，基質となる陽イオンの集積や結合に
寄与する。そこで，種間でよく保存された EMRE の酸性アミノ酸について変異体を構築し, $\mathrm{Ca}^{2+}$ 取 り込みに及ぼす影響を調べた。その結果，いずれの 変異体を発現させたミトコンドリアも野生型 EMRE と同等の $\mathrm{Ca}^{2+}$ 取り込夕活性を示した。この ことは, EMRE は直接 $\mathrm{Ca}^{2+}$ と結合して $\mathrm{Ca}^{2+}$ 取り 込みに寄与するのではないことを示唆している。 一 方で，酸性アミノ酸以外についても，様々な変異体 を構築して解析を行ったところ，Pro60 の変異体 （P60A）と Ser85-Asn90 を欠損した変異体 $(\Delta 85-90)$ では， $\mathrm{Ca}^{2+}$ 取り込みがまったく観察されなくなる ことがわかった [Fig. 3(A)].

5-2. EMRE と MCU の相互作用の重要性 P60A や $\Delta 85-90$ ではなぜ機能が消失したのであ ろうか？ EMRE は MCU と相互作用するタンパ ク質として同定されたので，機能を失った EMRE 変異体と MCU との相互作用に影響がないか免疫沈 降法により調べた。その結果，P60A と $\Delta 85-90$ は いずれも MCU と相互作用しないことが明らかに なった。この結果から，ミトコンドリアへの $\mathrm{Ca}^{2+}$ の取り込みには EMRE と MCU の相互作用が必須 であり，その相互作用には EMRE のマトリックス 側に位置するPro60 と細胞質側に位置する Ser85Asn90 が関与することがわかった [Fig. 3(B)] . EMRE は 1 回膜貫通型タンパク質であり, Pro60 は EMRE のマトリックス側に位置し，Ser85-Asn90 は細胞質側に位置している [Fig. 3(C)]。このこと から，EMRE と MCU は内膜を介した両側で相互 作用していることが示唆される。この両者の密接な 相互作用様式から，われわれは EMRE は MCU が 形成するチャネル孔を“開孔状態に固定する構造因 子”として機能していると考えられると結論した [Fig. 3(D)].

つい最近，クライオ電子顕微鏡により，ヒトの MCU と EMRE の複合体の立体構造が解明され

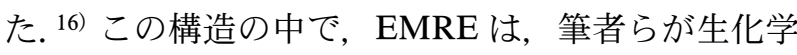
的な解析から予想した通り，開孔状態を固定するよ うに MCU の形成するチャネル孔に相互作用して存 在していることが明らかになった.

6. 構造機能解析から明らかになった MCU にお ける $\mathbf{C a}^{2+}$ 取り込みの調節機構

6-1. MCU のコイルドコイルドメインの機能的 な重要性カルシウムユニポーターのチャネル孔 
A

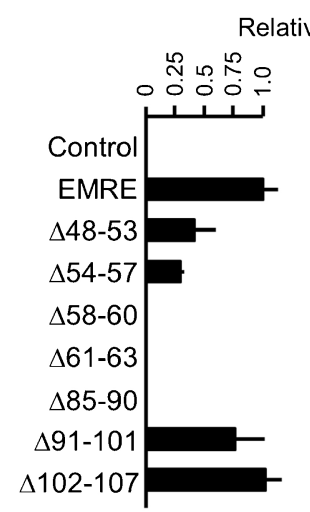

Relative $\mathrm{Ca}^{2+}$ uptake

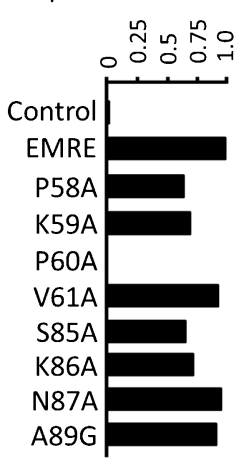

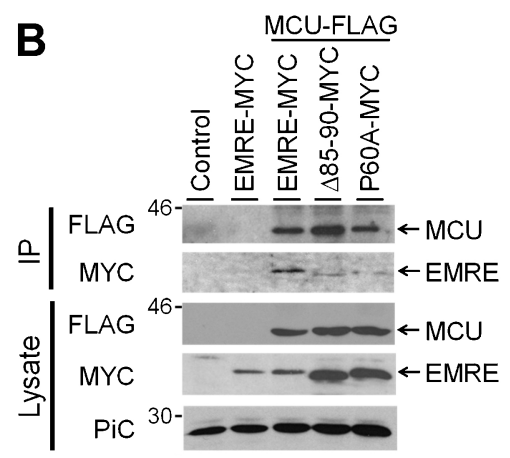

C

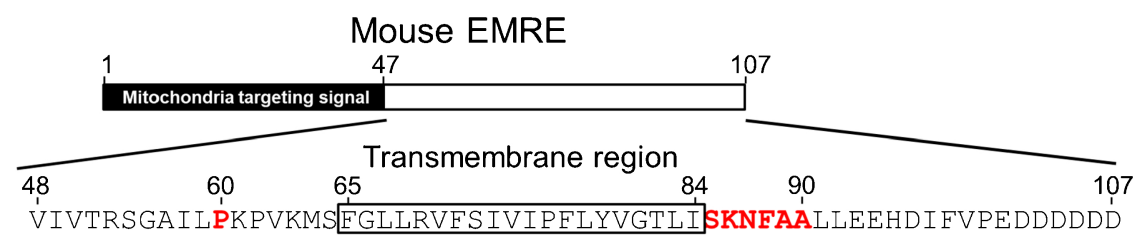

(Matrix)

(Cytosol)

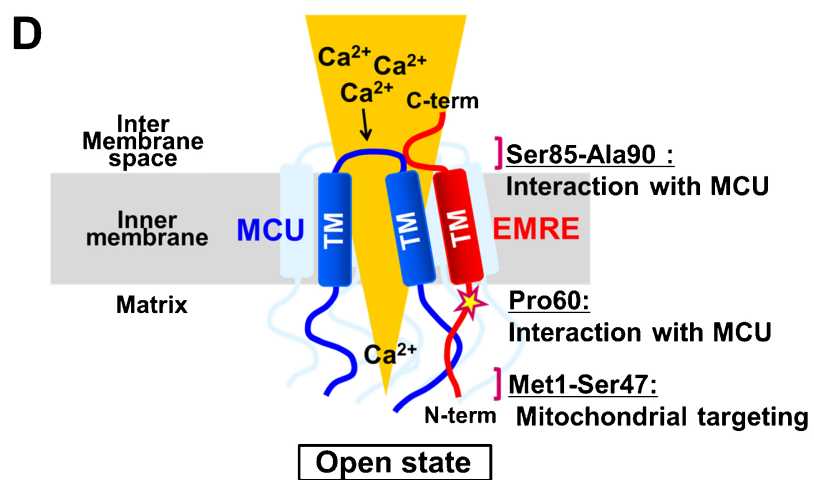

Fig. 3. Functional Analysis of EMRE Using Yeast Expression System

(A) Identification of amino acid regions in mouse EMRE critical for $\mathrm{Ca}^{2+}$ uptake. The activities of calcium uptake of the mitochondria isolated from the yeast with various mouse EMRE mutants were investigated; the relative $\mathrm{Ca}^{2+}$ uptake activities were shown in the histograms. (B) Identification of amino acid regions in the interaction between EMRE and MCU by imunoprecipitation of MCU and EMRE mutants with FLAG antibody. Mitochondria from yeast with MYC-tagged EMRE mutants with or without FLAG-tagged MCU were lysed (Lysate) and then subjected to immunoprecipitation by FLAG antibody conjugated to agarose gel; and the precipitant fractions (IP) were analyzed by immunoblotting. PiC (mitochondrial phosphate carrier) was used as loading controls for mitochondria. (C) The amino acid residue(s) playing an important role in the functions of EMRE. (D) Functional model of the roles of EMRE in mitochondrial calcium uptake. (Color figure can be accessed in the online version.)

を形成するサブユニットである MCU に関してはこ れまで最も精力的に研究が進められてきた. MCU は生物種間で広く保存されているが，2つの膜貫通 領域（TM1 と TM2）とその間に Asp と Glu で構 成された DXXE モチーフ, さらに 2 つ膜貫通領 域を挟むようにコイルドコイルドメイン（CC1 と CC2）を有している [Fig. 4(A)]. 17) これまでの研 究から, DXXE モチーフがイオンチャネルに必須 な構造である $\mathrm{Ca}^{2+}$ 選択性フィルターとして機能す ることが明らかにされた。しかし，DXXE モチー フ以外のドメインの機能や, $\mathrm{Ca}^{2+}$ が細胞質側の DXXE モチーフによって選別された後，どのよう
に内膜中やマトリックスに位置するドメインを通過 してマトリックス内に流入するのかはいまだ不明で あった，われわれは，先に確立した酵母再構成系を 使って，MCUの持つ種々のドメインに対する構造 機能解析を行った.

まず，マウス MCU の種々のアミノ酸領域を欠損 させた変異体を EMRE とともに酵母に発現させ, ミトコンドリアの $\mathrm{Ca}^{2+}$ 取り込み活性を調べた。そ の結果，2つのコイルドコイルドメイン（CC1 及び CC2）をそれぞれ欠損させた場合に $\mathrm{Ca}^{2+}$ 取り込み 機能が消失することが分かった [Figs. 4(B) and (C) ]. そこで, CC1 と CC2 におけるコイルドコイ 
A

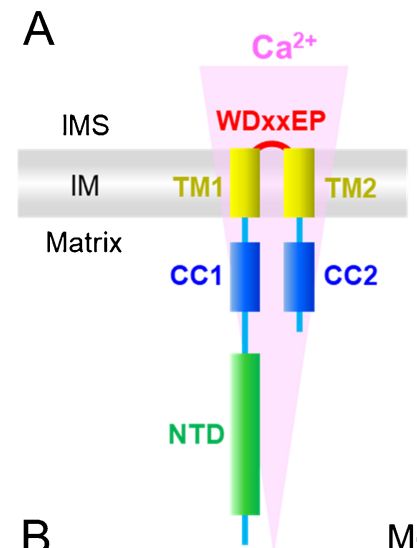

C

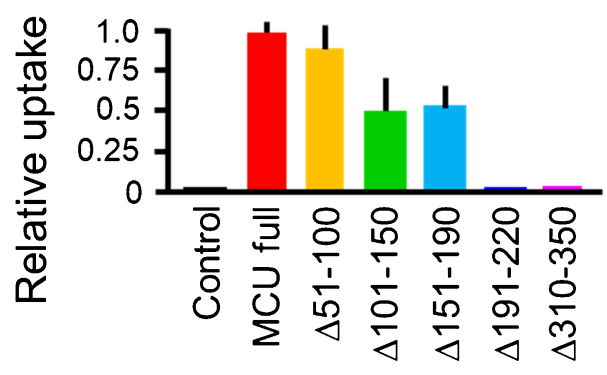

B

451-100

$\Delta 101-150$

$\Delta 151-190$

$\Delta 191-220$

$\Delta 310-350$

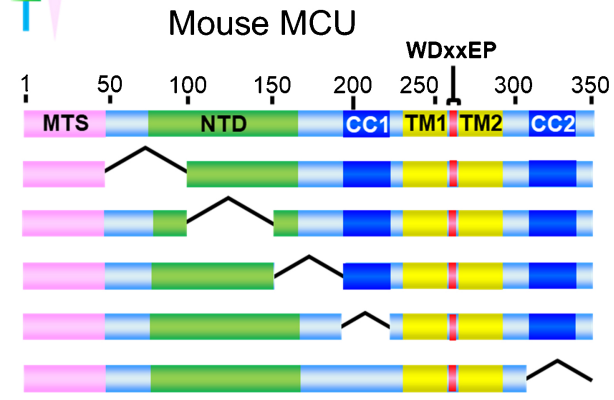

Fig. 4. Identification of Amino Acid Regions in Mouse MCU Critical for $\mathrm{Ca}^{2+}$ Uptake

(A) Domains/motifs and topology in mitochondrial inner membrane (IM) of mouse MCU. NTD, N-terminal domain; CC, coiled-coil domain; TM, transmembrane region. (B) Schematic representation of full-length MCU and its deletion mutants, showing predicted domains and motif. (C) The activities of calcium uptake in the mitochondria isolated from yeast with each MCU deletion mutant were compared. (Color figure can be accessed in the online version.)

ル構造の形成が $\mathrm{Ca}^{2+}$ 取り込み機能に必要なのかを 調べるために，コイルドコイル構造の形成を阻害す る点変異を $\mathrm{CC} 1$ 又は $\mathrm{CC} 2$ に導入したところ，いず れも $\mathrm{Ca}^{2+}$ 取り込み機能が消失した。このことから, $\mathrm{Ca}^{2+}$ 取り込みには MCU の CC1 と CC2 がそれぞ れコイルドコイル構造を形成することが必要である ことが示唆された。続いて，なぜ MCU のコイルド コイル構造が $\mathrm{Ca}^{2+}$ 取り込みに必要なのかを調べ た。過去に，MCU は調節サブユニットである MCUR1 及び EMRE と相互作用することが報告さ れている. しかしながら，われわれの解析から，両 ドメインの機能的重要性に MCUR1 や EMRE は無 関係なことが分かった。このことから，MCUの $\mathrm{CC} 1$ と CC2 は調節サブユニットとコイルドコイル 構造を形成するのではなく, CC1 と CC2 の間でコ イルドコイル構造を形成し，その構造が MCU の チャネル孔形成に重要であることを示唆してい た. ${ }^{18)}$

6-2. MCU の立体構造からみたコイルドコイル 構造の機能的役割 この 2 年間に, MCU の立体 構造が複数のグループにより相ついで報告された. Oxenoid らは $\mathrm{N}$ 末端ドメインを欠損させた線虫
$\mathrm{MCU}$ の立体構造を NMR で解析したところ， 5 量

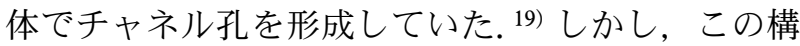
造モデルにおいて，コイルドコイルドメインは 5 本 の CC2 が 1 本の超らせん構造を形成する pentameric coiled coil を形成しており，CC1 はコイルド コイル構造をとらない状態で $\mathrm{CC} 2$ の pentameric coiled coil の周囲に存在していた。われわれの生化 学的な研究からは CC1 も CC2 もコイルドコイル構 造をとっていることが示されており，5量体モデル はわれわれの結果を反映していなかった。混乱した 状況がしばらく続いたが，その 2 年後，4つの独立 した研究グループから $\mathrm{N}$ 末端ドメインを含む真菌

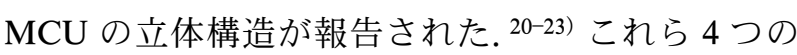
報告では，一転，いずれの MCU も 4 量体として チャネル孔を構成していた。 また，これらの構造中 では 2 つコイルドコイルドメイン $\mathrm{CC} 1$ と CC2 が アンチパラレルに配向してコイルドコイル構造を形 成していた。この MCU4 量体の構造的な特徵はわ れわれの生化学的知見と一致していた。ささに，わ れわれはこの真菌 MCU の立体構造を基に，マウス $\mathrm{MCU}$ の立体構造モデルを構築し，これまでの獲得 した生化学的解析の結果と照合を行った。その結 


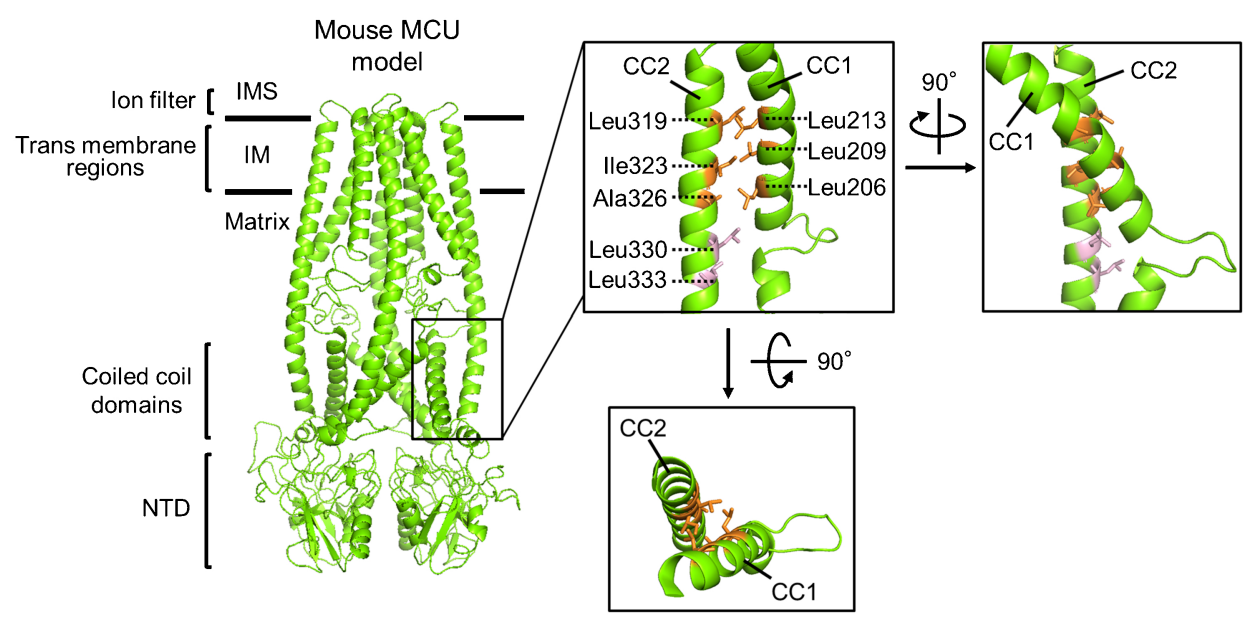

Fig. 5. Coiled-coil Structure in Mouse MCU Model

(Left) whole view of mouse MCU model based on the structure of C. europaea MCU determined by using SWISS MODEL. (Middle) and (Right) Close-up views of the coiled-coil structure. The hydrophobic amino-acid residues located at the position where CC1 and CC2 were the closest to one another are shown in orange. (Color figure can be accessed in the online version.)

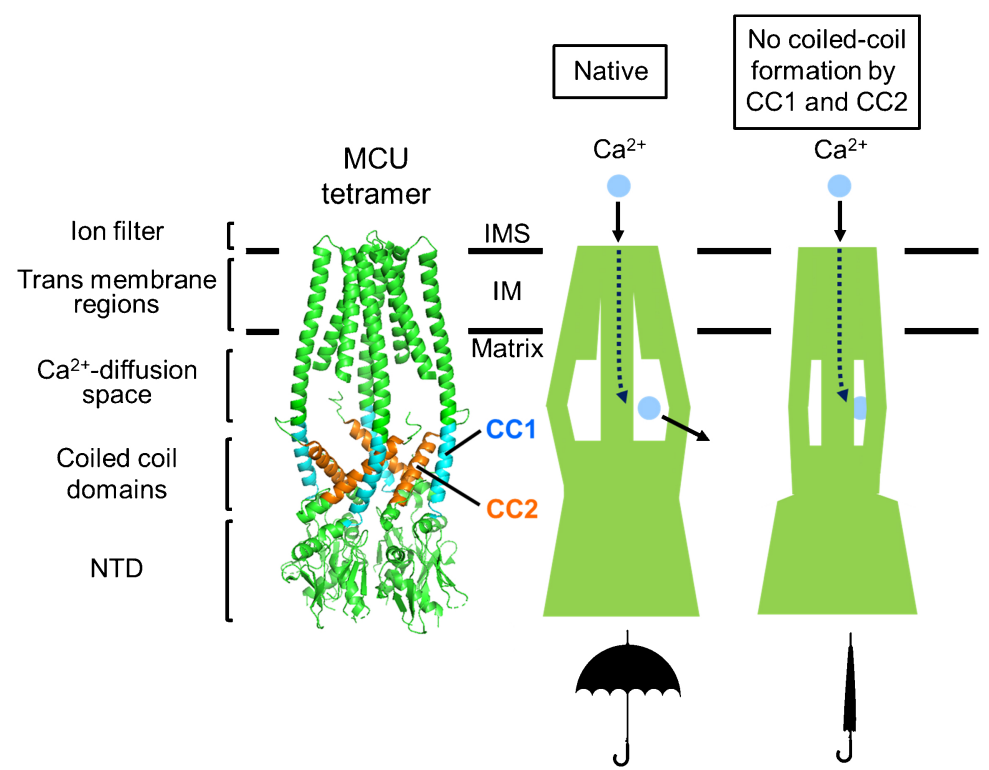

Fig. 6. Functional Model of Coiled-coil Domains of MCU

(Left) Structural model of mouse MCU. (Middle) there is ample space possible for $\mathrm{Ca}^{2+}$ to diffuse between the transmembrane region and coiled-coil domain; thus, $\mathrm{Ca}^{2+}$ which has passed the $\mathrm{Ca}^{2+}$ selective filter is considered to mainly enter into matrix through this space. (Right) when the formation of the coiled coil is inhibited by the deletion and point mutation, the space for $\mathrm{Ca}^{2+}$ diffusion would become narrow, as in the case of an umbrella that is closed, resulting in a probable decrease in $\mathrm{Ca}^{2+}$ uptake activity. (Color figure can be accessed in the online version.)

果，点変異解析で活性が消失した 6 つのアミノ酸残 基はすべてコイルドコイル構造を形成する 2 本の $\alpha$ ヘリックスの接合点に位置していることが確認され た（Fig. 5)。このことから，筆者らは，ミトコン ドリア内膜上で MCU のとっている構造に関して, 少なくとも $\mathrm{Ca}^{2+}$ 取り込みを行っている状態の MCU の場合には，4 量体構造モデルが生理的な構 造を反映していると考えている. 線虫 MCU が 5 量 体として観察された理由は不明であるが，MCUが
コンフォメーションを変化させる可能性, $\mathrm{N}$ 末端 ドメインの欠損による影響の可能性などが議論され ている.

マウスの立体構造モデルから, MCU4 量体のミ トコンドリア内部に露出した領域の中ほどに空洞が 観察され，ミトコンドリア外からイオン選択性フィ ルターを透過して侵入した $\mathrm{Ca}^{2+}$ はチャネル内腔か らこの空洞を通ってミトコンドリア内腔に拡散する ことが示唆された（われわれはこの空洞を $\mathrm{Ca}^{2+}$ - 
diffusion space と呼ぶ)。CC1 と CC2 が相互作用し て形成されるコイルドコイル構造はあたかも開いた 傘の骨組みを止めるストッパーの位置に当たり, チャネルの出口に当たる $\mathrm{Ca}^{2+}$-diffusion space を広 げる役割を果たしていることが推測される（Fig. 6). 18) 他のイオンチャネルのコイルドコイル構造が 機能に果たす役割の知見を基に考えると，MCU の コイルドコイル構造はチャネル孔の開閉を調節する スイッチとして機能している可能性も考えられる. その場合，このコイルドコイルドメインはミトコン ドリアへの $\mathrm{Ca}^{2+}$ 取り込みを制御する創薬を考える 上での有望な標的部位となり得ると考えられ，現在 このコイルドコイル構造を標的とした阻害ペプチド の開発に向けた取り組みを開始している.

\section{7. おわりに}

本稿では，筆者らが構築した酵母のミトコンドリ アに哺乳類のタンパク質を再構成するというユニー クな方法によって，MCU におけるカルシウムチャ ネル孔開閉の調節機能，及びそれを制御する EMRE の役割を明らかにした。この酵母再構成技 術は既に MCU 阻害剤の大規模スクリーニングにも 利用されており, ${ }^{24)}$ 今後の創薬開発への応用が期待 される．近年のクライオ電子顕微鏡を始めとする立 体構造解析の技術革新もあり，MCU がどのように $\mathrm{Ca}^{2+}$ を選択的にミトコンドリアの中に透過させる のか，EMRE がどのように $\mathrm{Ca}^{2+}$ 透過に係わるの か，という大きな命題に対しては多方面から知見が 集積されつつある。一方で，実際にミトコンドリア 膜上で，MCUにEMRE が何分子結合しているの か（化学量論比）という問題やアクセサリサブユ ニットの機能的役割については更なる研究が必要で ある。また，組織によってミトコンドリアの $\mathrm{Ca}^{2+}$ 取り込み活性が異なるメカニズムなど興味深い課題 はいまだ残されたままである。 今後も，カルシウム ユニポーターによる $\mathrm{Ca}^{2+}$ 輸送を制御する分子機構 を明らかにしていくことにより，ミトコンドリアの カルシウム取り込みを起点とする種々の疾患に対す る新たな治療薬の開発につながることが期待される.

謝辞本研究を進めるにあたり協力頂いた, 徳 島大学先端酵素学研究所 - 篠原康雄教授, 京都大学 大学院薬学研究科・矢野義明講師, 日本大学歯学 部・山本（山田）安希子助教に感謝いたします。ま
た, 故・寺田 弘 新潟薬科大学学長に感謝の意を 表するとともに冥福をお祈りいたします。また，山 越亮平博士を始め, ともに本研究を進めて頂いた徳 島大学・先端酵素学研究所・蛋白質発現分野の学生 諸氏に心より感謝の意を表します。文部科学省科学 研究費補助金基盤研究 C, 農林水産業・食品産業科 学技術研究推進事業, 興和生命科学振興財団, 武田 科学振興財団にご支援を頂きました。ここに感謝の 意を表します。

\section{利益相反＼cjkstart開示すべき利益相反はない.}

\section{REFERENCES}

1) Deluca H. F., Engstrom G. W., Proc. Natl. Acad. Sci. USA, 47, 1744-1750 (1961).

2) Gunter T. E., Pfeiffer D. R., Am. J. Physiol., 258, C755-C786 (1990).

3) Kirichok Y., Krapivinsky G., Clapham D. E., Nature, 427, 360-364 (2004).

4) Denton R. M., McCormack J. G., Biochem. Soc. Trans., 8, 266-268 (1980).

5) Jouaville L. S., Ichas F., Holmuhamedov E.L., Camacho P., Lechleiter J. D., Nature, 377, 438-441 (1995).

6) Duchen M. R., J. Physiol., 529, 57-68 (2000).

7) Perocchi F., Gohil V. M., Girgis H. S., Bao X. R., McCombs J. E., Palmer A. E., Mootha V. K., Nature, 467, 291-296 (2010).

8) Baughman J. M., Perocchi F., Girgis H. S., Plovanich M., Belcher-Timme C. A., Sancak Y., Bao X. R., Strittmatter L., Goldberger O., Bogorad R. L., Koteliansky V., Mootha V. K., Nature, 476, 341-345 (2011).

9) De Stefani D., Raffaello A., Teardo E., Szabò I., Rizzuto R., Nature, 476, 336-340 (2011).

10) Plovanich M., Bogorad R. L., Sancak Y., Kamer K. J., Strittmatter L., Li A. A., Girgis H. S., Kuchimanchi S., De Groot J., Speciner L., Taneja N., Oshea J., Koteliansky V., Mootha V. K., PLoS One, 8, e55785 (2013).

11) Raffaello A., De Stefani. D., Sabbadin D., Teardo E., Merli G., Picard A., Checchetto V., Moro S., Szabò I., Rizzuto R., EMBO J., 32, 2362-2376 (2013).

12) Mallilankaraman K., Cárdenas C., Doonan $P$. J., Chandramoorthy H. C., Irrinki K. M., Golenár T., Csordás G., Madireddi P., Yang 
J., Müller M., Miller R., Kolesar J. E., Molgó J., Kaufman B., Hajnóczky G., Foskett J. K., Madesh M., Nat. Cell Biol., 14, 1336-1343 (2012).

13) Sancak Y., Markhard A. L., Kitami T., Kovács-Bogdán E., Kamer K. J., Udeshi N. D., Carr S. A., Chaudhuri D., Clapham D. E., Li A. A., Calvo S. E., Goldberger O., Mootha V. K., Science, 342, 1379-1382 (2013).

14) Logan C. V., Szabadkai G., Sharpe J. A., et al., Nat. Genet., 46, 188-193 (2014) .

15) Yamamoto T., Yamagoshi R., Harada K., Kawano M., Minami N., Ido Y., Kuwahara K., Fujita A., Ozono M., Watanabe A., Yamada A., Terada H., Shinohara Y., Biochim. Biophys. Acta Bioenerg., 1857, 831839 (2016).

16) Wang Y., Nguyen N. X., She J., Zeng W., Yang Y., Bai X. C., Jiang Y., Cell, 177, 12521261 (2019).

17) Bick A. G., Calvo S. E., Mootha V. K., Science, 336, 886 (2012).

18) Yamamoto T., Ozono M., Watanabe A., Maeda K., Nara A., Hashida M., Ido Y., Hiroshima Y., Yamada A., Terada H., Shino- hara Y., Biochim. Biophys. Acta Bioenerg., 1860, 148061 (2019).

19) Oxenoid K., Dong Y., Cao C., Cui T., Sancak Y., Markhard A. L., Grabarek Z., Kong L., Liu Z., Ouyang B., Cong Y., Mootha V. K., Chou J. J., Nature, 533, 269-273 (2016).

20) Yoo J., Wu M., Yin Y., Herzik M. A. Jr., Lander G. C., Lee S. Y., Science, 361, 506511 (2018).

21) Nguyen N. X., Armache J. P., Lee C., Yang Y., Zeng W., Mootha V. K., Cheng Y., Bai X. C., Jiang Y., Nature, 559, 570-574 (2018).

22) Fan C., Fan M., Orlando B. J., Fastman N. M., Zhang J., Xu Y., Chambers M. G., Xu X., Perry K., Liao M., Feng L., Nature, 559, 575-579 (2018).

23) Baradaran R., Wang C., Siliciano A. F., Long S. B., Nature, 559, 580-584 (2018).

24) Arduino D., Wettmarshausen J., Vais H., Navas-Navarro P., Cheng Y., Leimpek A., Ma Z., Delrio-Lorenzo A., Giordano A., Garcia-Perez C., Médard G., Kuster B., GarcíaSancho J., Mokranjac D., Foskett J. K., Alonso M. T., Perocchi F., Mol. Cell, 67, 711-723 (2017). 